\title{
К.Н. Тихомиров
}

Институт археологии и этнографии СО РАН просп. К. Маркса, 15, Омск, 644024

E-mail: ktikhomirov@gmail.com

\section{СЕИТОВО IV - НОВЫЙ МОГИЛЬНИК ПРЕДКОВ ТАРСКИХ ТАТАР XVII-XVIII вВ. В СРЕДНЕМ ПРИИРТЫШЬЕ}

\begin{abstract}
Рассматриваются результаты раскопок на грунтовом могильнике Сеитово IV, находящемся в южно-таежной зоне Среднего Прииртышья (Западная Сибирь). На основе анализа материала выделяются особенные черты в погребальном обряде. Это прежде всего особенности расположения погребенного в яме: зафиксированное сдвигание умершего от центра могилы к одной из ее стенок, положение одного скелета на боку, смещение костей с одной стороны к позвоночнику, возможно вызванное подкладыванием под тело какого-нибудь предмета. Полученные материалы (две московские денги времени Ивана IV) дали возможность уверенно датировать комплекс, а анализ письменных источников XVIII в. позволил предположить, что могильник был оставлен предками тарских татар.
\end{abstract}

Ключевые слова: Западная Сибирь, Среднее Прииртышье, предки тарских татар, грунтовый могильник Сеитово IV, особые черты в погребениях, XVI-XVIII в8.

DOI: 10.20874/2071-0437-2019-45-2-059-068

\section{Введение}

История Западной Сибири периода перед началом освоения этих территорий выходцами из европейской части Российского царства, несмотря на многолетние исследования, до сих пор остается мало известной. И если лучшему пониманию первых годов проживания переселенцев из европейской части на новой земле может способствовать небольшой корпус источников, то о местном населении сведения практически отсутствуют. Тем не менее это важнейший период слома традиций и формирования нового в культурном отношении населения, начала формирования современных народов Сибири, в том числе сибирских татар. Его изучение поможет ответить на важнейшие вопросы культурогенеза.

Одними из наиболее исследованных территорий Среднего Прииртышья - традиционного места проживания предков сибирских татар XVI-XVIII вB. являются районы среднего и нижнего течения р. Тары. Здесь были проведены раскопки на нескольких могильниках. Наиболее полно опубликованы лишь Окунево VII [Матющенко, 2003; Матющенко, Полеводов, 1994], Бергамак II [Корусенко, 2003; Татауров, Тихонов, 1995; Тихомиров, 2012], Кыштовка II [Молодин, 1979] и Крючное 6, создавшие мощную базу для реконструкции погребального обряда населения указанных территорий.

В этих же районах в середине 1990-х - начале 2000-х гг. был проведен сбор информации о погребальных ритуалах среди населения современных татарских деревень и обследованы современные кладбища тарских татар [Корусенко, 1996, 1998; Корусенко и др., 1999; Селезнев, Мерзликин, 1994]. Вышла монография М.А. Корусенко [2003], в которой он, обобщив опубликованные и неопубликованные материалы раскопок С.С. Тихонова на могильнике Бергамак II и проанализировав этнографические данные, предложил вариант реконструкции множества элементов погребального обряда тюркоязычного населения низовьев р. Тары XVII-XX вв. Эти работы создали хорошую базу для реконструкции погребального обряда начиная с эпохи позднего средневековья. Однако они не раскрывали его в более ранние периоды.

\section{Материалы исследования}

Впервые сведения о могильнике были получены автором в 2012 г. от жителей д. Сеитово, передавших в дар перстень и остатки медного котла, а также позволивших сфотографировать бронзовую бляшку [Тихомиров, 2013, с. 229; 2018, с. 12, 13, 149, рис. 2, 5]. Жители села сообщили, что на территории этого памятника на протяжении длительного времени периодически производились работы по изъятию грунта для ремонта домов, в том числе с применением бульдозера, к тому же поверхность памятника периодически распахивалась. Это привело к уничтожению большей части памятника и нарушению дневной поверхности, в результате этого все внешние проявления захоронений, если они были, снивелированы. 


\section{К.Н. Тихомиров}

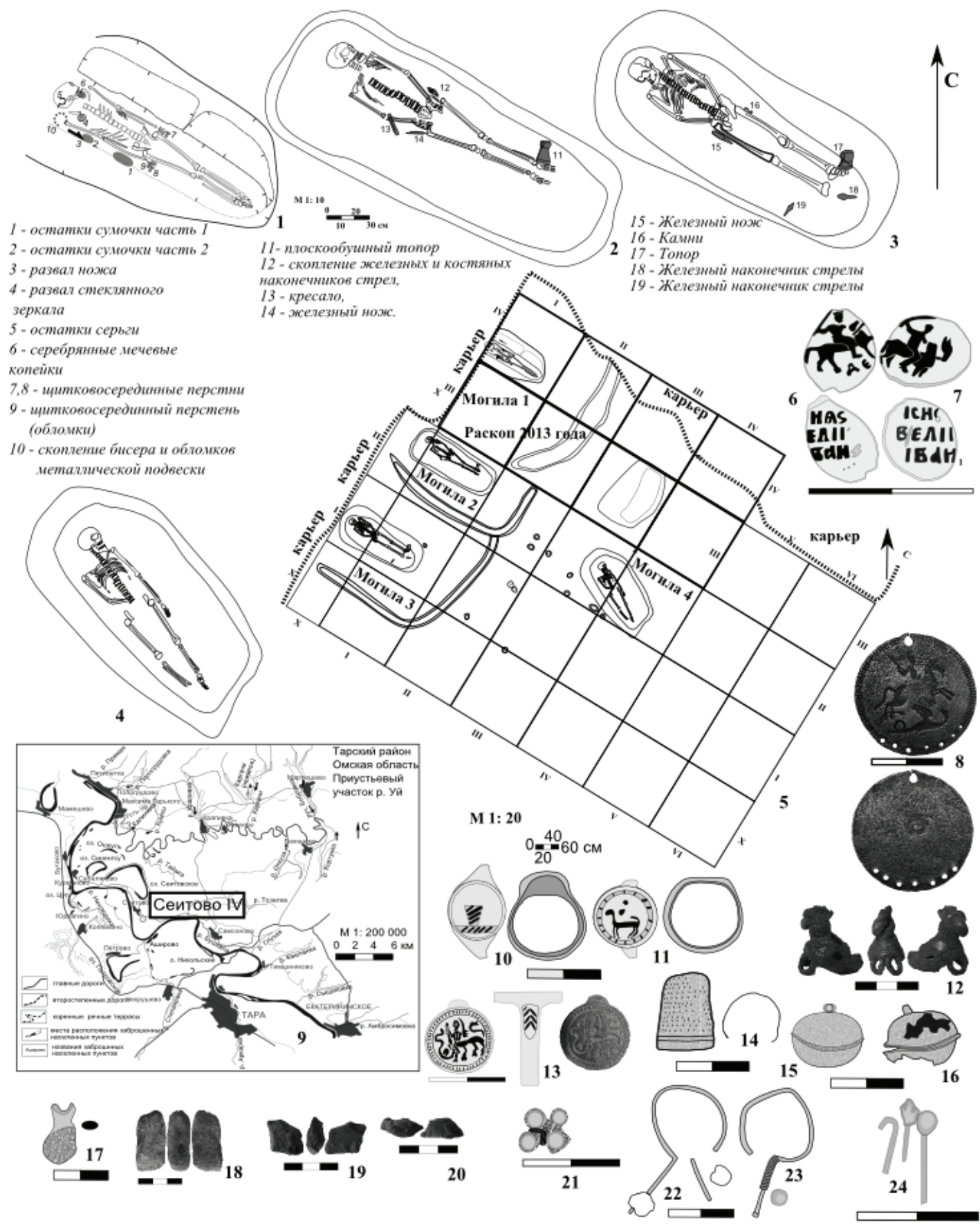

Рис. 1. Планы расположения могильника Сеитово IV, общий план раскопов, планы погребений, инвентарь из объектов и с территории могильника:

1 - план погр. 1; 2 - план погр. 2; 3 - план погр. 3; 4- план погр. 4; 5- общий план объектов; 6, 7 - московские денги (аверс и реверс); 8 - бляшка (часть украшения); 9 - план расположения памятника; 10, 11 - перстни; 12 - полая орнитоморфная подвеска; 13 - перстень с территории могильника; 14 - наперсток; 15, 16 - бубенчики; 17 - обломок пуговицы; 18-20 - камни; 21 - нашивка; 22, 23 - серьги; 24 - бронзовые изделия: 6, 7, 10, 11, 14-17, 21-24 - погребение 1; 18-20 погр. 3; 8, 12, 13 - территория памятника: 6, 7- серебро; 8, 10-13, 17, 22-24 - бронза; 21 - белый металл; 18-20-камень.

Fig.1. Plans for the location of the Seitovo IV burial ground, a general excavation plan, entombment plans, inventory from the object and from the burial grounds:

1 - plan of the sepulture $1 ; 2$ - entombment plan 2;3- sepulture plan $3 ; 4$ - entombment plan $4 ; 5$ - the general plan of graves and fosses; 6, 7-Moscow money (obverse and reverse side of the coin); 8 - plaque (piece of bijouterie); 9 - plan of the location of the monument; 10,11 - rings; 12 - hollow orintomorfny pendant; 13 - ring from the burial ground; 14 - thimble; 15, 16 - sleighbells 17 - button fragment; 18-20 - stone; 21 - badge; 22, 23 - earrings; 24 - bronze artefacts: 6, 7, 10, 11, 14-17, 21-24 - grave 1; 18-20 - grave 3; 8, 12, 13 - territory of the site: 6, 7- silver; 8, 10-13, 17, 22-24 - bronze; 21 - white metal; 18-20 — stone. 


\section{Сеитово IV - новый могильник предков тарских татар XVII-XVIII вB. в Среднем Прииртышье}

Грунтовый могильник Сеитово IV находится на правом берегу р. Иртыша между устьями рек Тара и Уй, на южной окраине д. Сеитово Тарского района Омской области, в 15 км к северозападу от г. Тары (рис. 1, 9), на бровке первой надпойменной правобережной террасы Иртыша.

В 2013 и 2015 гг. на памятнике были проведены аварийно-спасательные работы на площади $151 \mathrm{~m}^{2}$, на участке, прилегающем к западной стенке современного карьера между ним и бровкой террасы. В площадь раскопа попали четыре могилы и ровики вокруг них (рис. 1,5$)$.

Погребение 1 (рис. 1, 1). Яма была неправильной овальной фрормы, размерами 179×127 см, глубиной 39 см. Вокруг нее фиксировался ровик, северная часть которого была уничтожена карьером.

В яме находилось погребение по обряду трупоположения - вытянуто на спине головой на запад - северо-запад. Весь скелет был сдвинут к южной стенке. Отмечено, что его кости с левой стороны были смещены к позвоночнику и лежали ниже правой стороны. Вероятно, при погребении тело лежало на боку, опираясь правой стороной на стенку могильной ямы. Предварительно можно предположить, что это погребение взрослого индивида (женщины?).

Сопроводительный инвентарь составили: щитковые перстни (рис. 1, 10, 11), остатки сумочки для рукоделий, обломки железного ножа (рис. 2, 5), обломки серег в виде «?» (рис. 1, 22, 23), раздавленное стеклянное зеркало, две московские денги времени Ивана IV (Грозного) (рис. 1, $6,7)$, остатки сумочки для рукоделия с бисером, бусами, наперстком и т.д.

Погребение 2 (рис. 1, 2). Яма была неправильной овальной формы, размерами $248 \times 98$ см, глубиной 52 см, ориентирована вдоль условной линии запад-северо-запад - восток-юговосток. Вокруг могилы фриксировался ровик. Его западная часть была уничтожена карьером.

В яме находилось погребение по обряду трупоположения - вытянуто на спине головой на запад - северо-запад. Отмечается, что скелет сдвинут к северной стенке могилы, а кости левой руки смещены к позвоночнику, ключица и лопатка сдвинуты к черепу. Предварительно можно предположить, что это погребение взрослого индивида (мужчины?).

Сопроводительным инвентарем являлись: вильчатый наконечник с остатками древка и изделие в виде одношипного наконечника стрелы с отверстием посередине, выполненные из медных пластин (рис. 2, 8, 7), компактное скопление железных и костяных наконечников стрел (у левого бедра) (рис. 1, 2; 2, 9-12, 15-18), железный топор (рис. 2, 1) (у левой ступни, почти касаясь ее), лезвием направленный к костям, железный нож с остатками рукояти (рис. 2, 4), найденный на дне могилы с правой стороны от тазовых костей, и железное плоское прямоугольное кресало с отверстием, прорубленным посередине (рис. 2, 6), у тазовых костей с правой стороны на дне могилы (под правым локтем).

Погребение 3 (рис. 1, 3). Яма имела форму неправильного овала, ориентированного вдоль условной линии запад-северо-запад - восток-юго-восток. Ее размеры 225×93 см, глубина 49 см. У могилы фриксировался ровик. На юго-западной окраине ровика было обнаружено скопление костей животного и неорнаментированной лепной керамики. Можно предположить, что это были остатки тризны.

В могиле находилось погребение по обряду трупоположения - вытянуто на спине головой на запад - северо-запад. Скелет сдвинут к северной стенке ямы, а ключицы и предплечья с левой стороны смещены к позвоночнику. Предварительно можно предположить, что это погребение взрослого индивидуума (мужчины?).

В яме были найдены: у левой ступни железный топор (рис. 2, 2), прислоненный обухом к стенке могилы, лезвие уходило под кости ступни и упиралось в дно ямы; железный нож у пояса с правой стороны (рис. 2, 3); два железных плоских ромбических наконечника стрел (рис. 2, 13, 14); с левой стороны от пояса было обнаружено скопление из четырех камней, предназначение которых осталось неизвестно (рис. 1, 18-20).

Погребение 4 (рис. 1, 4). Его размеры 178×95 см при глубине 44 см. Ровика у могилы не фриксировалось.

В могиле находилось погребение по обряду трупоположения - вытянуто на спине головой на север - северо-запад. Скелет сдвинут к северной стенке ямы, а ключицы и предплечья с левой стороны смещены к позвоночнику. Предварительно можно предположить, что это погребение взрослого индивидуума (мужчины?).

Инвентарь, обнаруженный в погребениях, находит широкие аналогии в материалах могильников XVII-XVIII вв. в Западной Сибири. 


\section{К.Н. Тихомиров}

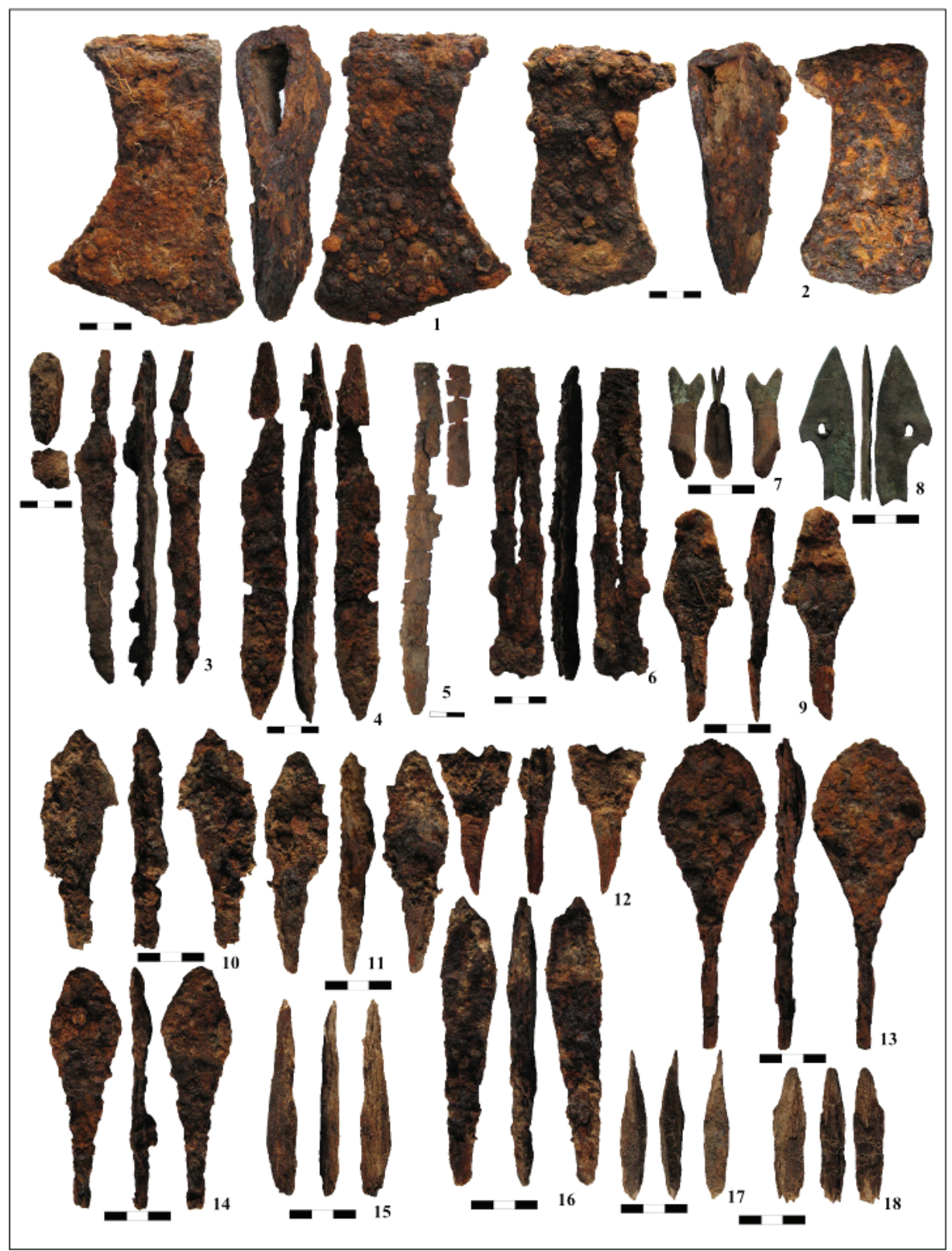

Рис. 2. Инвентарь из могил:

1, 2 - топоры; 3 - нож и остатки рукояти; 4- нож; 5 - нож и остатки накладок на рукоять; 6 - кресало;

7 - наконечник стрелы с остатками древка; 8- изделие из меди в виде наконечника стрелы; 9-12, 15-18 - наконечники стрел из скопления (погр. 2); 13,14 - наконечники стрел: 5 - погр. 1; 1, 4, 6-12, 15-18 - погр. 2 ; 2, 3, 13, 14 - погр. 3: 7, 8 - медь; 15, 17, 18 - кость, остальное - черный металл.

Fig. 2. Inventory from the graves:

1, 2 - axes; 3 - the knife and the remains of the handle; 4 - a knife; 5 - a knife and the remains of overlays on a handle; 6 - fire steel ; 7 - arrowhead with the rest of the shaft; 8 - copper product in the form of an arrowhead;

9-12, 15-18 - arrowheads from congeries (grave 2): 5- grave 1; 1, 4, 6-12, 15-18 - grave 2; 2, 3, 13, 14 - grave 3: 7, 8 - copper; 15, 17, 18 - bone, the rest is ferrous metal.

Топоры (2 экз.). Оба железные проушные плоскообушные без бородки. Наиболее близкие аналоги орудию из могилы 3 имеются в материалах раскопок Искера [Соловьев, 1987, с. 95, рис. 31, 2]. Топор из могилы 2 находит более широкие аналогии, ближайшие из которых - орудия с могильников Окунево VII [Матющенко, 2003, рис. 78, 4], Бергамак II [Тихомиров, 2012, с. 196, рис. 10, 1], Кыштовка II [Молодин, 1979. с. 161, табл. XXIX, 2, 3, 5] и др. Топоры, подобные описываемым, бытуют с конца XVI в. [Соловьев, 1987, с. 96-98]. 


\section{Сеитово IV — новый могильник предков тарских татар XVII-XVIII вв. в Среднем Прииртышье}

Ножи (3 экз.). Все они располагались острием к костям ступней. Два из них находились на дне могильной ямы в районе тазовых костей с правой стороны. А нож из могилы 1 обнаружен выше дна могилы (на 23 см), на куске бересты вместе с остатками сумочки для рукоделия, над правой плечевой костью. Он был в остатках ножен с остатком жесткого крепления к поясу, что позволяет предположить наклонный способ ношения на поясе, широко распространенный среди средневекового населения Западной Сибири [Сирелиус, 1907, с. 63; Соловьев, 1987, с. 82]. Рукоять была смонтирована накладным способом с плашками из дерева. На хвостовике и плашках фиксировались три крепежных отверстия. В одном из них (ближнем к торцу рукояти, чуть смещенном к спинке) были остатки медной клепки. Два изделия (из могил 1 и 2) были в остатках ножен.

Ножи, найденные на могильнике, также имеют широкие аналогии среди материалов Западной Сибири. Они появляются на этих территориях в середине I тыс. н.э. и существуют до прихода русских [Молодин, 1979, с. 75; Соловьев, 1987, с. 88]. Территориально ближайшие аналоги им находятся на грунтовых могильниках Бергамак II [Татауров, Тихонов, 1996, с. 74; Тихомиров, 2012; 2016, с. 143], Окунево VII [Матющенко, 2003, рис. 23, 2; 78, 3; 88, 1; Матющенко, Полеводов, 1994, рис. 67, 3; 65, 26; 79, 6], Кыштовка II [Молодин, 1979].

Наконечники стрел (11 шт.) и медное стреловидное изделие. Девять наконечников были обнаружены в погребении 2 и еще два в могиле 3. Среди них вильчатый плоский наконечник стрелы с остатками древка (в могиле 2) был выполнен из медной пластины лежал на 4 см выше дна могилы над скоплением стел (рис. 2, 7). Указанное скопление находилось слева от костей таза (у гребня подвздошной кости) на дне могилы, остриями к ногам (рис. 1, 2). Все входившие в него металлические наконечники относились к плоским ромбическим без упора с наибольшим расширением в верхней трети и к плоским ромбическим без упора с наибольшим расширением в нижней трети. Первый вариант, согласно А.И. Соловьеву, был распространен в Западной Сибири в VIII-XIV вв., второй появляется во второй половине II тыс. и существует до «этнографической современности» [1987, с. 38]. Все костяные (2 экз.) были трехгранными. Наконечники в могиле 3 относились к плоским крупным ромбическим с упором и к плоским ромбическим без упора.

В заполнении ямы (на 45 см выше дна могилы) было обнаружено изделие в виде плоского медного одношипного наконечника стрелы с отверстием (рис. 2, 8)

Железные и костяные проникатели находят широкие аналогии среди как материалов этого времени (ближайшие - на могильниках Окунево VII [Матющенко, 2003, рис. 66, 1-6; 79, 1, 6, 7; 88, 5-9; Матющенко, Полеводов, 1994, с. 198, рис. 79, 4, 5, 7], Бергамак II [Корусенко, 2007, с. 166 , рис. $51,2,6$, 8; Тихомиров, 2012, с. 194, рис. 8, 1-4, 8, 9] и др.), так и более ранних периодов [Коников, 2007]. Наконечники из медных пластин встречаются значительно реже. Все найденные в Среднем Прииртышье указанные изделия с отверстием сделаны на правобережье р. Тары (поселение Усть-Тара LIXX [Тихомиров, 2014, с. 9, 9] и Бергамак III [Мельников, 1996, с. 86, рис. 2, 4], могильник Крючное-6 [Молодин и др., 2012, с. 50, рис. 19]). Медный вильчатый наконечник с остатками древка уникален.

Все украшения и предметы быта были найдены в могиле 1.

Сумочка для рукоделия. Ее остатки представляли собой куски из бересты, обшитой различной, в том числе шелковой, тканью разного цвета, развалившейся на три части ${ }^{1}$. Они обнаружены в заполнении ямы на 23 см выше скелета. В сумочке находились: медный наперсток (рис. 1, 14); два бронзовых бубенчика (рис. 1, 15, 16); крупный бисер синего цвета; мелкий металлический бисер; два (одно сломанное) крестообразных металлических изделия (белый металл), одно с остатками нити (рис. 1, 21); обломок бронзовой пуговицы (рис. 1, 17); три бронзовых проволочных изделия (рис. 1, 24). Одно из последних было с загнутой петелькой, два других с металлическими бусинками на концах. Это позволяет предположить, что это остатки булавок. Две бронзовые булавки были также найдены на могильнике Кыштовка II [Молодин, 1979, с. 99].

Территориально ближайшими аналогиями являются скопление бус и бисера из могильника Усть-Тара LXX [Tихомиров, 2016, с. 116-117, 146, рис. 37] и набор предметов для рукоделия на могильнике Бергамак II [Корусенко, 2003, с. 35; Татауров, Тихонов, 1996, с. 78-79]. Остатки сумочки встречались и на могильнике Кыштовка II [Молодин, 1979, с. 28, 41] и городище Частухинский Урий [Семенова, 2005, с. 22, 80-86, рис. 51].

Бубенчики (2 экз.). Найдены в могиле 2 среди указанных выше остатков. Один целый, другой сломанный, с остатками нити на ушке. Внутри него обнаружено било (металлическая горо-

${ }^{1}$ Благодарю Т.Н. Глушкову за определение остатков тканей. 


\section{К.Н. Тихомиров}

шина). Оба были составлены из двух полусфер. Подобные изделия довольно широко распространены на памятниках этого времени в Западной Сибири, ближайшие найдены на могильниках Бергамак II [Корусенко, 2003, с. 157, рис. 42, 6; Тихомиров, 2012, с. 195, рис. 9, 3], Садовка 4 [Молодин и др., 1990, с. 86, рис. 63, 32], Кыштовка II [Молодин, 1979, с. 95]. Встречаются такие изделия, но несколько иной формы и в более ранних материалах из Среднего Прииртышья [Коников, 2007, с. 429 , рис. $215,4,7,9,14,15]$.

Наперсток. Находился в том же комплексе. Такие изделия довольно широко распространены среди материалов XVI-XVIII вв. в Западной Сибири. Наиболее близкими к ним являются находки на могильниках Окунево VII [Матющенко, Полеводов, 1994, рис. 78, 16], Бергамак II [Tатауров, Тихонов, 1996, с. 72, рис. 6, 2; с. 77, рис. 8, 2], Кыштовка II (6 экз.), о которых В.И. Молодин пишет, что это был предмет русского импорта [1979, с. 99-100].

Зеркало. В могиле 1 на 3-4 ребрах справа были обнаружены остатки овального стеклянного зеркала. Его размеры $65 \times 50$ см при толщине 2 мм. Территориально ближайшими аналогами являются зеркала из могильника Бергамак II [Корусенко, 2003, с. 99; Тихомиров, 2012, с. 167]. В целом анализ подобных предметов на могильниках этого времени провела М.Н. Ландик [1997], поэтому не будем подробно на этом останавливаться. Считается, что стеклянные зеркала являлись предметом русского экспорта в Сибирь [Молодин, 1979, с. 97].

Монеты (2 экз.) (рис. 1, 6, 7). Были получены после извлечения черепа из могилы. Они находились в районе челюстей, что позволяет предполагать, что на момент погребения они были в ротовой полости. Обе монеты это московские денги. Время чеканки монет находится в пределах второй-третьей четвертей XVI в. (1538-1561 гг.).

Следует отметить, что обнаруженные в ближайших могильниках этого времени монеты Русского царства были более поздние (Окунево VII [Матющенко, Полеводов, 1994, с. 108], Бергамак II [Археологическая карта..., 2000, с. 34], Кыштовка II [Молодин, 1979, прил. 3, с. 126130, табл. XXVIII, с. 160]). Однако аналогичные монеты встречены в погребении 9 могильника Моховая XLVI рядом с г. Сургутом [Стефанов, 2002, с. 198, 209; Сургутский краеведческий музей..., 2011, с. 101, № 271-274].

Перстни (3 экз.). В результате работ на могильнике получена небольшая коллекция щитковых перстней. Два бронзовых (рис. 1, 10, 11) и один из белого металла найдены в погребении 1. Один с территории памятника (рис. 1, 13). На правой руке находились перстень с круглым щитком с изображением какого-то кошачьего хищника и обломки другого, из белого металла; форму щитка и изображение на последнем восстановить невозможно. На левой руке находился бронзовый перстень с круглым щитком. Изображение на нем видно лишь частично (это заштрихованные полосы). Подобные изделия широко распространены на указанных могильниках.

Серьги (2 экз.). В погребении 1 в районе черепа был обнаружен комплекс предметов, состоящий из куска бересты и обломков серег из бронзовой проволоки в виде «?». Данный тип в указанный период широко распространен на территории Западной Сибири. Территориально ближайшие аналогии находятся в материалах могильников Усть-Тара LXX [Тихомиров, 2016, с. 116], Бергамак II [Тихомиров, 2016, с. 144, рис. 35, 9, 10], Кыштовка II [Молодин, 1979, с. 178, табл. XLVI], Крючное 6 [Молодин и др., 2012, с. 26, рис. 18, 18), на комплексе памятников на Татарском увале у д. Окунево [Могильников, 1997, рис. 9, 5; Матющенко, 2003, рис. 5, 18; 73, 3, 4; Матющенко, Полеводов, 1994, рис. 68, 28]. Такие изделия на памятниках Западной Сибири подробно проанализировали Б.В. Мельников и Г.В. Холостых. Сделан вывод, что они в основном привозились из европейской части России, где были распространены в XIII-XVIII вв., а самые простые изготавливались местным населением [Мельников, Холостых, 1994, с. 211].

Кресало. Прямоугольное двухлезвийное. Было обнаружено в погребении 2 в районе правого локтя. Представляет собой прямоугольную металлическую пластину (черный металл) с прорубленным в центре длинным отверстием. Подобные кресала довольно редкого типа. Однако их находки отмечены среди материалов Искера, в материалах как М.С. Знаменского [Зыков и др., 2017, рис. 13, 21], так и более поздних раскопок [Там же, рис. 113, 3, 7]. В целом же можно сказать, что в Западной Сибири преобладали однолезвийные калачевидные кресала. Ближайшие происходят из могильников Окунево VII [Матющенко, 2003, рис. 23, 6; Матющенко, Полеводов, 1994, рис. 70, 11], Кыштовка II [Молодин, 1979, с. 86].

Инвентарь с территории могильника. За время исследования жителями д. Сеитово автору были показаны три предмета: обломки медной посуды (котла), бронзовый щитковый перстень с фигуурой кентавра, борющегося со змеем (рис. 1, 13), и бронзовая бляшка с изображением всадни- 


\section{Сеитово IV — новый могильник предков тарских татар XVII-XVIII вв. в Среднем Прииртышье}

ка, поражающего змея (часть составного украшения) (рис. 1, 8). Два последних были подробно описаны в отдельной публикации [Тихомиров, 2018, с. 12, 13, 149, рис. 2, 5]. Котлы, выполненные из меди, довольно широко распространены на могильниках этого времени на территории Западной Сибири. Ближайшие аналоги найдены на могильниках Окунево VII [Матющенко, 2003, рис. 22, 69; 1, 80], Бергамак II [Корусенко, 2003, рис. 53; 55, 10; Татауров, 1997], Кыштовка II [Молодин, 1979, с. 83, 84] и, по мнению В.И. Молодина, являются в основном русским экспортом [Там же, с. 85].

Вызывает интерес находка на территории могильника в южной части раскопа бронзовой полой орнитоморфной подвески (рис. 1, 12). Она находилась вне комплекса и явно была перемещена (на территории могильника велась распашка). Аналоги ей имеются в материалах X-XIII вB. в Среднем Прииртышье (усть-ишимская культура). Ближайшие встречаются среди материалов курганного могильника Аргаиз I в Знаменском районе Омской области [Коников, 2007, с. 136, 457, рис. 289, 291].

\section{Обсуждение результатов и основные выводы}

Проведенные во время исследования наблюдения позволяют сделать выводы о некоторых чертах погребального обряда, датировке могильника и культурной принадлежности проживавшего здесь населения.

На могильнике явно выделялась группа могил (1-3), расположенных компактно практически ровно в ряд, идущий поперек террасы в одной системе ровиков, и отдельно располагалась еще одна (4). Погребения 1-3 содержали инвентарь и были ориентированы практически идентично запад - северо-запад, а погребение 4 - более повернуто к северу.

Заполнение могильных ям состояло из двух частей. В центре располагалось пятно светлосерой перемешанной супеси в форме эллипса, которое имело четкие границы, маркированные темно-серой супесью. Данный контур черно-серой супеси четко прослеживался и в заполнении могильной ямы. Продольные и поперечные стратиграфические разрезы заполнения показали, что данные пятна не заполняли весь объем, ни в глубину, ни в ширину, ни в длину. Скелеты и инвентарь лежали ниже пятен.

Положение скелетов позволяет заключить, что при погребении тело умершего, видимо, смещали относительно условной длинной оси могильной ямы к одной из стенок и располагали так, что кости скелета с одной стороны оказывались сдвинутыми к позвоночнику. А в погребении 1 тело положили на бок, прислонив к стенке могильной ямы. Учитывая это и тот фракт, что скелеты находились под линзой светло-серой супеси, закономерно будет предположить, что сначала погребенного присыпали грунтом, затем обожгли яму, после чего ее засыпали грунтом.

Таким образом, указанные погребения на могильнике Сеитово IV имеют ряд общих черт с хронологически и территориально близкими им комплексами (трупоположение вытянуто на спине, головой на северо-запад, наличие ровиков вокруг ямы, схожий погребальный инвентарь и т.д.), но есть и особенности. Это четко зафриксированная группа из трех могил, со следами схожих действий при погребении (одинаковый способ заполнения могильных ям, помещение в яму инвентаря). Также здесь везде наблюдается смещение скелета к одной из стенок могилы. Вызывает интерес тот факт, что в настоящее время татары помещают тело в устроенный в стенке могилы подбой, вследствие чего оно оказывается сдвинутым относительно центра ямы [Корусенко, 2003, с. 61; Тихомирова, Тихомиров, 2018, с. 132]. Отмечается, что кости у всех погребенных с одной стороны смещены к позвоночнику; это могло быть вызвано упором тела во что-нибудь или тем, что при погребении под одну из его сторон что-либо подкладывали. В одном случае засвидетельствовано положение тела на бок, прислоненным к стенке ямы. Такая практика фриксируется при захоронениях у татар Западной Сибири. Так, у тюменских и тобольских татар дно в подбое делалось наклонным, и «фактически покойный оказывался чуть повернутым на бок» [Селезнев, Мерзликин, 1999, с. 123], а у татар в Кемеровской области зафиксирован обычай подкладывать под спину покойного комок грунта, «чтобы он был повернут на Киблу» [Тихомирова, Тихомиров, 2018, с. 132].

О датировке могильника следует сказать, что его нижняя хронологическая граница определяется по найденным монетам концом XVI в., верхняя, по аналогиям в инвентаре и некоторым чертам погребального обряда на могильниках этого времени (Окунево VII, Бергамак II, Кыштовка II и др.), - XVIII в.

О культурной принадлежности населения позволяют судить письменные источники. В начале XVIII в. на своих картах С.У. Ремезов указывает, что на этом месте проживали «туралы» и «аялы» [Хорографическая книга..., 2011, л. 92]. Позже Г.Ф. Миллер отмечает здесь лишь населенные пункты татар [Сибирь в путевых заметках..., 1996, с. 90]. Это же подтверждают источники конца XVII в. [Томилов, 1981, с. 137-140]. Это позволяет предположить, что могильник ос- 


\section{К.Н. Тихомиров}

тавлен предками тарских татар. Таким образом, погребения входят в круг подобных, характерных для расположенных поблизости синхронных могильников тюркоязычного населения этого региона, и маркируют наиболее ранний этап фрормирования погребального обряда предков аялынской и туралинской групп тарских татар.

\section{БИБЛИОГРАФИЧЕСКИЙ СПИСОК}

Археологическая карта Муромцевского района Омской области / М.Ю. Здор, С.Ф. Татауров, К.Н. Тихомиров. Омск: ОмГУ, 2000. 135 с.

Борзунов В.А., Стефранов В.И. Могильники «Бардаковского княжества» // Интеграция археологических и этнографических исследований. Омск: Изд-во ОмГПУ, 1999. С. 240-244.

Зыков А.П., Косинцев П.А., Трепавлов В.В. Город Сибир - городище Искер: (Историко-археологическое исследование). М.: Наука: Вост. лит., 2017. 559 с.

Коников Б.А. Омское Прииртышье в раннем и развитом средневековье. Омск: Изд-во ОмГПУ: Наука, 2007. $466 \mathrm{c}$.

Корусенко М.А. Зиярат д. Инцисс (Муромцевский район Омской области) // Этнографо-археологические комплексы: Проблемы культуры и социума. Новосибирск: Наука, 1996. Т. 1. С. 117-149.

Корусенко М.А. Кладбище д. Берняжка Большереченского района Омской области // Этнографоархеологические комплексы: Проблемы культуры и социума. Новосибирск: Наука, 1998. Т. 3. С. 161-216.

Корусенко М.А. Погребальный обряд тюркского населения низовьев р. Тара в XVII-XX вв.: Опыт анализа структуры и содержания // Этнографо-археологические комплексы: Проблемы культуры и социума. Новосибирск: Наука, 2003. Т. 7.

Корусенко М.А., Мерзликин В.В., Селезнев А.Г. Погребальный комплекс у д. Юрт-Бергамак // Этнографоархеологические комплексы: Проблемы культуры и социума. Новосибирск: Наука, 1999. Т. 1. С. 149-183.

Ландик М.Н. Зеркало в погребальном обряде населения низовьев р. Тары // Интеграция археологических и этнографических исследований. Омск; СПб: ОмГУ, 1998. Ч. ІІ. С. 4-6.

Матющенко В.И. Могильник на Татарском увале у д. Окунево (Ом VII): Раскопки 1998, 1999 годов. Омск: ОмГУ, 2003. 64 с. (Новое в археологии Прииртышья; Вып. 3).

Матющенко В.И., Полеводов А.В. Комплекс археологических памятников на Татарском увале у деревни Окунево. Новосибирск: Наука, 1994. 233 с.

Мельников Б.В. Поселение Бергамак III: (Предварительное сообщение) // Этнографо-археологические комплексы: Проблема культуры и социума. Новосибирск: Наука, 1996. Т. 1: Культура тарских татар. С. 84-91.

Могильников В.А. Позднесредневековые материалы из комплекса памятников у дер. Окунево в Тарском Прииртышье: (К проблеме происхождения тарских татар) // Вестник археологии, антропологии и этнографиии. 1997. Вып. 1. С. 51-64.

Молодин В.И. Кыштовский могильник. Новосибирск: Наука, 1979. 184 с.

Молодин В.И., Новиков А.В., Поздняков Д.В., Соловьев А.И. Позднесредневековые комплексы на озере Крючное (Средняя Тара). Новосибирск: НГУ, 2012. 162 с.

Молодин В.И., Соболев В.И., Соловьев А.И. Бараба в эпоху позднего средневековья. Новосибирск: Наука, 1990. 262 с.

Селезнев А.Г., Мерзликин В.В. Кладбище у деревни Юрт-Бергамак: Предварительные результаты исследования // Таре - 400 лет: Материалы науч.-практ. конфр. Омск; Тара: Изд-во ОмГТУ. 1994. Ч. 2. С. 99-101.

Семенова В.И. Поселение и могильник Частухинский Урий. Новосибирск: Наука, 2005. 164 с.

Сирелиус У.Т. Домашние ремесла остяков и вогулов // ЕТГМ. Тобольск: Тип. Епарх. братства, 1907. Вып. 16. С. 41-69.

Сибирь XVIII века в путевых описаниях Г.Ф. Миллера. История Сибири. Первоисточники. Новосибирск: Сиб. хронограф, 1996. Вып. VI. 310 с.

Соловьев А.И. Военное дело коренного населения Западной Сибири: Эпоха средневековья. Новосибирск: Наука, 1987. 193 с.

Стесранов В.И. Моховая XLVI - позднесредневековый могильник Сургутского Приобья // ХантыМансийский автономный округ в зеркале прошлого. Томск; Ханты-Мансийск, 2002. Вып. 1. С. 164-210.

Сургутский краеведческий музей. Археологическое собрание: Каталог. Екатеринбург; Сургут: Магеллан, 2011. 152 с.

Татауров С.Ф. «История» двух котлов // Четвертые исторические чтения памяти М.П. Грязнова. Омск: ОмГУ, 1997. С. $144-148$.

Татауров С.Ф., Тихонов С.С. Могильник Бергамак II // Этнографо-археологические комплексы: Проблема культуры и социума. Новосибирск: Наука, 1996. Т. 1: Культура тарских татар. С. 58-83.

Тихомиров К.Н. Раскопки 1999 года на могильнике Бергамак II // Этнографо-археологические комплексы: Проблемы культуры и социума. Омск: Издатель-Полиграфист, 2012. Т. 12. С. 162-198.

Tихомиров К.Н. Два перстня XVI-XVIII веков из Среднего Прииртышья: К вопросу о формировании повседневного пространства // Творчество в археологическом и этнографическом измерении. Омск: Наука, 2013. C. 229-234. 


\section{Сеитово IV - новый могильник предков тарских татар XVII-XVIII вв. в Среднем Прииртышье}

Тихомиров К.Н. Город Тара как центр экономического и культурного развития сибирских татар в Тарском Прииртышье в XVI-XVIII веках // Тара в XVI-XIX веках - российская крепость на берегу Иртыша. Омск: Амфора, 2014. С. 187-223.

Тихомиров К.Н. Визуальный анализ кладбищ тюркоязычного населения Среднего Прииртышья и археологические материалы из могильников XVI-XVIII веков в низовьях р. Тары // Этнографоархеологические комплексы народов Тарского Прииртышья: Могильники, погребальный обряд и мир мертвых в свете этноархеологических работ. Омск: Наука, 2016. (Этнографо-археологические комплексы: Проблемы культуры и социума; Т. 14). С. 66-147.

Тихомиров К.Н. Изображения всадников на предметах XVI-XVIII веков из археологических коллекций Среднего Прииртышья // Декабрьские диалоги: Материалы Всерос. науч. конф. памяти Ф.В. Мелехина. Омск: Абсолют, 2018. Вып. 21. С. 12-13, 149.

Тихомирова М.Н., Тихомиров К.Н. Современные некрополи татар Кемеровской области как источник для историко-сравнительных исследований // Интеграция археологических и этнографических исследований. Омск: Наука, 2018. С. 128-132.

Томилов Н.А. Тюркоязычное население Западно-Сибирской равнины в конце XVI - первой четверти XIX вв. Томск: Изд-во ТГУ, 1981. 276 с.

Хорограффическая чертежная книга С.У. Ремезова. Тобольск, 2011. 629 с.

K.N. Tikhomirov

Institute of Archeology and Ethnography of Siberian Branch RAS K. Marx av., 15, Omsk, 644024, Russian Federation E-mail: ktikhomirov@gmail.com

\section{SEITOVO 4: A NEW BURIAL GROUND OF THE TARA TATARS' ANCESTORS OF THE 17th-18th CENTURIES IN THE MIDDLE IRTYSH AREA}

Due to the work of archaeologists and ethnographers, the funeral ceremony of the population having inhabited the middle and lower stretch of the Tara river (southern taiga zone of Western Siberia) at the end of the 17th18th centuries has been quite extensively studied. However, little has been known thus far about its early period (late 16th - early 17th century) and the ethno-cultural identity of the people who buried the dead there. The discovery of coins during excavations conducted at Seitovo 4 - a burial ground located on a right bank of the Irtysh river on the southern outskirts of the eponymous village in Tarsky district, Omsk region - allowed the burial dates to be established. The above-mentioned coins of the Russian Tsardom (Moscow 'denga' minted in 1538-1561) belonged to the time of monetary reform under the rule of Ivan the Terrible. The data analysis revealed some specific features of the burial ceremony: grouping the graves in one complex; moving the body to one of the grave walls (usually northern); displacing the bones of the deceased on one side towards the spine; special actions when filling the grave pit; firing the burial pit and the area around it, etc. In addition, rare and unique things were found, including a forked arrowhead made from a copper plate with shaft remains; an article made from a copper plate in the form of a flat arrowhead with a single barb and a hole in the middle; a rectangular double-edged firesteel. At the same time, the features typical of burial grounds of the 17th-18th centuries widespread in the region were present: one burial under a mound in pits recessed into the ground; construction of ditches around the pit; traditional inventory (arrowheads, iron knives, axes, earrings, signet rings etc.); positioning the deceased on their back, with head to the north-north-west, etc. This shows that the complex belonged to their circle, constituting the earliest part of the funeral rite of the Tara Tatars' ancestors during the specified period. The analysis of written sources (first half of the 17th - first half of the 18th century) reveals that only Tatars, mostly the Ayali group, lived there at that time. Thus, assuming that the buried belonged to the specified group, conclusions can be drawn about the individual features of the burial rite.

Key words: Western Siberia, Middle Irtysh area, the ancestors of the Tara Tatars, Seitovo IV burial ground, special features in the burials, 16-18th centuries.

DOI: 10.20874/2071-0437-2019-45-2-059-068

\section{REFERENCES}

Borzunov V.A., Stefanov V.I. (1999). The burial grounds of the «Bardak principality». Integraciya arheologicheskih $i$ ehtnograficheskih issledovanij (pp. 240-244), Omsk: Izdatel'stvo Omskogo gosudarstvennogo universiteta.

Konikov B.A. (2007). The Omsk Irtysh river basin in the Early and Developed Middle Ages, Omsk: Izdatel'stvo Omskogo gosudarstvennogo pedagogicheskogo universiteta: Nauka.

Korusenko M.A. (1996). Ziyarat village Inciss (Muromtsevsky district of Omsk region). Ehtnografoarheologicheskie kompleksy: Problemy kul'tury i sociuma, 1 (pp. 117-149), Novosibirsk: Nauka.

Korusenko M.A. (1998). Cemetery of the village of Bernyazhka, Bolsherechensky вistrict, Omsk кegion. Ehtnografo-arheologicheskie kompleksy: Problemy kul'tury i sociuma, 3 (pp. 161-216), Novosibirsk: Nauka.

Korusenko M.A. (2003). The funeral rite of the Turkic population of the downstream country of the Tara river in the 18-20th centuries: Experience in analyzing the structure and content. Ehtnografo-arheologicheskie kompleksy: Problemy kul'tury i sociuma, 7, Novosibirsk: Nauka. 


\section{К.Н. Тихомиров}

Korusenko M.A., Merzlikin V.V., Seleznyov A.G. (1999). Funerary complex near the village of Yurt-Bergamak. Ehtnografo-arheologicheskie kompleksy: Problemy kul'tury i sociuma, 1 (pp. 149-183), Novosibirsk: Nauka.

Landik M.N. (1998). Mirror in the burial rite of the population of the downstream country Tara river. Integraciya arheologicheskih i ehtnograficheskih issledovanij, II (pp. 4-6), Omsk; St. Petersburg.

Matyushchenko V.I. (2003). Burial ground on Tatarsky uvaly near the village of Okunevo (Om VII): Excavations 1998, 1999, Omsk: Omskij gosudarstvennyj universitet.

Matyushchenko V.I., Polevodov A.V. (1994). The complex of archaeological sites in Tatarsky uval near the village of Okunevo, Novosibirsk: Nauka.

Mel'nikov B.V. (1996). Bergamak III settlement: (Preliminary report). Ehtnografo-arheologicheskie kompleksy: Problema kul'tury i sociuma, 1 (pp. 84-91), Novosibirsk.

Miller G.F. (1996). Siberia of the 18th century in the travel descriptions, Novosibirsk: Sibirskij hronograf.

Mogil'nikov V.A. (1997). Late Medieval materials from the complex of sites near the village of Okunevo in Tara Irtysh river basin: (On the problem of the origin of the Tara Tatars). Vestnik arheologii, antropologii i ehtnografii, (1), 51-64.

Molodin V.I. (1979). Kyshtovsky burial ground, Novosibirsk: Nauka.

Molodin V.I., Novikov A.V., Pozdnyakov D.V., Solov'yov A.I. (2012). Late medieval complexes on lake Kruchnoe (Middle Tara river), Novosibirsk: Novosibirskij gosudarstvennyj universitet.

Molodin V.I., Sobolev V.I., Solov'ev A.I. (1990). Baraba in the Late Middle Ages, Novosibirsk: Nauka.

Remezov S.U. (2011). Horography drawing book, Tobol'sk.

Seleznyov A.G., Merzlikin V.V. (1994). Cemetery near the village of Yurt-Bergamak: Preliminary results of the study. Tare - 400 let, 2 (pp. 99-101), Omsk; Tara.

Selyanina M.Yu., Trufanov A.Ya. (Eds.) (2011). Surgut museum of local lore. Archaeological collection: Catalog, Ekaterinburg; Surgut: Magellan.

Semenova V.I. (2005). Settlement and burial Chastuhinsky Uriy, Novosibirsk: Nauka.

Sirelius U.T. (1907). Ostyak and Vogul crafts. Ezhegodnik Tobol'skogo gubernskogo muzeya, (16), Tobol'sk: Tipografiya Eparhial'nogo bratstva, 41-69.

Solov'yov A.I. (1987). Military affairs of the indigenous population of Western Siberia: The Middle Ages, Novosibirsk: Nauka.

Stefanov V.I. (2002). Mokhovaya XLVI, the Late Medieval burial ground of the Surgut Ob river basin. HantyManskijskij avtonomnyj okrug v zerkale proshlogo, (1), (pp. 164-210), Tomsk; Hanty-Mansijsk.

Tataurov S.F. (1997). "Story» of two boilers. Chetvertye istoricheskie chteniya pamyatni Mihaila Petrovicha Gryaznova (pp. 144-148), Omsk.

Tataurov S.F., Tihonov S.S. (1996). Burial ground Bergamak II. Ehtnografo-arheologicheskie kompleksy: Problema kul'tury i sociuma, 1 (pp. 58-83), Novosibirsk.

Tihomirov K.N. (2012). Excavations of 1999 on the burial ground of Bergamak II. Ehtnografoarheologicheskie kompleksy: Problemy kul'tury i sociuma, 12 (pp. 162-198), Omsk: Izdatel'-Poligrafist.

Tihomirov K.N. (2013). Two seal-rings of the 16-18th centuries from the Middle Irtysh: On the formation of everyday space. Tvorchestvo $v$ arheologicheskom $i$ ehtnograficheskom izmerenii (pp. 229-234), Omsk: Nauka.

Tihomirov K.N. (2014). The city of Tara as the centre of the economic and cultural development of the Siberian Tatars in the Tara Irtysh river in the 16-18th centuries. Tara v XVI-XIX vekah - rossijskaya krepost' na beregu Irtysha (pp. 187-223), Omsk: Amfora.

Tihomirov K.N. (2016). Visual analysis of the cemeteries of the Turkic-speaking population of the Middle Irtysh and archaeological materials from the burial grounds of the 16-18th centuries in the downstream country of the Tara river. Ehtnografo-arheologicheskie kompleksy narodov Tarskogo Priirtysh'ya: Mogil'niki, pogrebal'nyj obryad i mir mertvyh v svete ehtnoarheologicheskih rabot (pp. 66-147), Omsk: Nauka.

Tihomirov K.N. (2018). Images of riders on objects of the 16-18th centuries from the archaeological collections of the Middle Irtysh. Dekabr'skie dialogi, (21) (pp. 12-13, 149), Omsk.

Tihomirova M.N., Tihomirov K.N. (2018). Modern necropolis of the Tatars of the Kemerovo region as a source for historical and comparative research. Integraciya arheologicheskih i ehtnograficheskih issledovanij (pp. 128-132), Omsk: Nauka.

Tomilov N.A. (1981). The Turkic-speaking population of the West Siberian Plain at the end of the 16th - first quarter of the 19th centuries, Tomsk: Izd-vo Tomskogo gosudarstvennogo universiteta.

Zdor M.Yu., Tataurov S.F., Tihomirov K.N. (Eds.) (2000). Archaeological map of Muromtsevsky district of Omsk region, Omsk: Omskij gosudarstvennyj universitet.

Zykov A.P., Kosincev P.A., Trepavlov V.V. (2017). City of Sibir, the Isker hillfort: (Historical and archaeological research), Moscow: Nauka: Vostochnaya literatura.

(cc) EY

This work is licensed under a Creative Commons Attribution 4.0 License.

Submitted: 25.02 .2019

Accepted: 01.04.2019

Article is published: 28.06.2019 